\title{
After the millennium development goals: Remarks on the ethical assessment of global poverty reduction success
}

\section{Teppo Eskelinen}

Department of Social Sciences and Philosophy, University of Jyväskylä, Finland teppo.h.i.eskelinen@jyu.fi

DOI: http://dx.doi.org/10.5324/eip.v12i1.2348

(cc) BY $\quad$ This is an open access article distributed under the terms of the Creative Commons Attribution 4.0 International License, which permits unrestricted use, distribution, and reproduction in any medium, provided the original author and source are credited.

The Millennium Development Goals were effective from 2000 to 2015. Statistics show that most of the goals were met, and particularly success in the goal of reducing extreme poverty (MDG1) gained wide recognition. Despite the strong ethical language related to poverty reduction, there has been little analysis of the ethical significance of the MDG achievements. Since statistical and ethical definitions and representations of poverty never completely overlap, conclusions concerning ethical progress are not directly available from the statistics. This article shows how this ethical significance can be analysed and what kinds of controversies and uncertainties relate to the issue. As part of this analysis, utilitarian issues, population ethics, and the social aspect of poverty are discussed.

Keywords: poverty, Millennium Development Goals, statistics, ethics, poverty line

\section{Introduction}

The United Nations' Millennium Development Goals (MDGs), effective 2000-2015, were the most ambitious and co-ordinated global attempt to eliminate poverty to date. The goals were formed as an outcome of a process that included several international top summits on issues such as sustainable development and hunger. While the methodology and the exact definition of the MDGs have been criticised (Pogge 2004), the level of global co-ordination and commitment to development goals were unprecedented.

The MDGs included a number of targets, such as combating HIV and malaria and improving maternal health. The first of the eight goals (MDG1) rose above the rest in visibility, to the extent that it has become almost synonymous with 'poverty reduction'. This goal aimed to halve the proportion of the extremely poor by 2015 (WHO 2017). The fact that the goal was reportedly met already in 2012 was a cause for celebration and seen as a sign of tremendous progress (UN 2015a; UN 2015b; Galatsihas \& Sheedy 2015). The successes of the MDGs have been widely noted and acclaimed, even after the expiration of the MDG period in 2015.

Despite the publicity sparked by this success, remarkably little ethical analysis of the meaning of the MDG period has occurred, even though the results themselves 
have been well publicised. Instead, statistical results have dominated the discussion. While philosophers have written extensively about poverty (e.g. Nagel 2008; O'Neill 2008; Pogge 2008), this discussion has typically taken the form of contemplation on the ethical responsibilities of rich individuals (Singer 2008; Kuper 2002; Cullity 2004; Horton \& Roche 2010), while actual attempts to assess real-word poverty reduction ethically have been missing. This is a clear deficiency.

The purpose of this article is to provide starting points for an ethical interpretation of the change documented by the statistical indicators, which inform the MDG process. The article will proceed as follows. First, I will discuss the specific conceptualisations of poverty assumed as the basis of the MDG process, and make some initial remarks on what the statistics show about poverty trends. Second, I will make some methodological remarks about global poverty statistics; how they include errors of margin and fail to recognise a 'borderline' state between poverty and liberation from poverty. Third, I will dig more deeply into ethical theory and pose questions on 1) what kinds of ethical conclusions should be derived from poverty reduction that is accompanied by population growth, and 2) the possible suffering of some people as an outcome of the same policies that reduce aggregate poverty. Fourth, I will discuss the social and contextual nature of poverty before offering my conclusions in the final chapter.

\section{The birth of current poverty reduction targets and the meaning of poverty}

The intuitive meaning of 'poverty' is very clear. It is typically easy to recognise extreme poverty when seeing a clear manifestation of it, such as a chronically undernourished person. Yet giving a definition to poverty is far more challenging. Official documents often refer to some conditions associated with poverty when ostensibly defining it, for example: 'Its manifestations include hunger and malnutrition' (UN 2016). Sometimes they merely use strong visual images in place of a definition. Charity organisations in particular permeate their communications with strong ethical language, such as 'the fight against poverty' (ONE 2016), 'changing lives' (POP 2016), and so forth.

Philosophical ethics often approaches poverty by asking what is evil about it. In The Companion to Ethics, for example, Nigel Dower defines poverty as consisting of three evils. First, poverty significantly shortens life; second, it involves great suffering and pain; and third, it undermines the essential dignity and decency of human life (Dower 1991: 277-278). Similarly, the UN refers to the 'dehumanising conditions of extreme poverty' (UN 2000: \$11) and defines poverty as 'a condition characterised by severe deprivation of basic human needs, including food, safe drinking water, sanitation facilities, health, shelter, education and information', or the 'denial of choices and opportunities' (Gordon 2005).

Poverty is then typically defined both in philosophy and in some formal accounts as consisting of suffering, along with a lack of dignity and normal functioning capability. The utilitarian school associates poverty with suffering, seeing poverty as bad because suffering is bad (Singer 2008, Unger 1996). The capability school sees human beings first and foremost as autonomous subjects, and argues that poverty is bad since it hinders the realisation of basic human capabilities (Nussbaum 2001; Sen 1999). Poverty is thus seen as a lack of functionings rather than as abjective notion of possessing or accessing some given goods. ${ }^{1}$ Further, the human rights approach combines elements of both, seeing access to given basic amenities and 
services as a natural right belonging to all human beings, thus making extreme poverty a violation of rights (Sane 2010, Campbell 2007). All these schools see poverty as an unquestionable evil, even if strictly speaking it is more often seen as a cause of ethically evil things rather than evil as such. ${ }^{2}$

In the MDG discourse, by contrast, poverty refers to a statistical phenomenon. This statistical approach equates poverty with a failure to command an amount of goods needed for a decent life. Further, commanding a given amount of money is seen as a sufficient metric for the possession of these basic goods. Each individual is categorised as being either above or below a 'poverty line'. 'Poverty' is then approached as a headcount of individuals below this given line. This conception of poverty is reflected in all World Bank data (World Bank 2017a), and therefore, in all data on 'global poverty'. Interestingly, this approach gained prominence within the MDG process, while simultaneously most of the world of international development was moving towards more nuanced indicators, such as the Human Development Index (UNDP 2018).

While the existence of myriad potential definitions of poverty is often acknowledged, the moral significance and intuitive clarity of the matter sometimes invite frustration over meticulous definitional attempts. What is the point of quarrelling over definitional details or philosophical points, when people are dying from malnutrition and preventable diseases? Yet as in all politics, definitions inform policy, and it is precisely the great moral significance of poverty reduction that calls for clarity in how it is defined. Any poverty reduction policy must assume some conception of poverty as to what exactly is to be reduced. Definitions always highlight some aspects of the phenomenon and depreciate others, as they necessarily involve choices. Further, since poverty reduction policy is designed to be efficient given the existing definition, incorrect or inadequate conceptualisations are likely to lead to incorrect or inadequate solutions.

The statistical approach has of course been chosen for a reason: the virtue of the clarity of quantitative measurement. Statistical time-series allow exact comparison over time, thus enabling scientific discourse on poverty reduction. In international politics, an ambiguous commitment is often a non-commitment. When political leaders commit themselves to 'promote' solutions or 'acknowledge' problems, it is difficult to show that they have not lived up to their promises. However, when they commit themselves to meeting a quantitatively defined target, meeting or not meeting this target can be clearly demonstrated. Yet in evaluating the successes of global poverty reduction, it is necessary to note the limitations of the quantitative approach. While low purchasing power very typically coincides with suffering and lack of capabilities (apart from rare cases of voluntary poverty, see Rahnema 1992: 160), some elements of poverty-related suffering can be ignored by the quantitative approach. Statistics are not insignificant, but they come with limitations that ethicists should be aware of.

\section{Statistical trends and initial reservations}

In general terms, MDG statistics show a trend of 'real but uneven progress' (UN 2015c). 'Real' means that there has been a reduction of income poverty, no matter which of the two global poverty lines is chosen (daily income of US $\$ 1.08$, adjusted to US\$1.90 or US\$2.00, adjusted to US\$3.10) (World Bank 2017a, World Bank $2017 b)$. 'Uneven' means that tremendous growth of intra-country inequalities has 
accompanied the witnessed poverty reduction (Sumner 2012), and that the pace of progress is markedly different in different geographical areas.

Indeed 'global' poverty reduction appears considerably less global when one analyses the available data in terms of geographical variation. Progress is concentrated in given areas, particularly in China. This is best demonstrated by using figures on global poverty reduction excluding China. In such figures, one sees only a modest decrease in poverty levels during this millennium when the lower poverty line (US\$1.08) is applied, and the number of the people below the higher poverty line (US\$2.00) remains roughly constant from 1980 onwards. This implies that the global success of meeting the MDG1 is to a quite large extent a Chinese phenomenon. This does not only mean that progress is slower in other areas; in subSaharan Africa, the number of the extremely poor has in fact increased between 2000 and 2015 (World Bank 2017b). This of course makes the achieved poverty reduction no less important as the distribution of progress has no moral significance as such - a person liberated from poverty in China is as important as this occurring anywhere else - but it calls for caution in interpreting the phenomenon as 'global'. This is because global poverty is expressed as a common concern, calling for concerted action. Even if not seen as a direct outcome of global politics, the ethical assessment of the 'global' MDGs is affected if the progress seems to be pronouncedly local. While no less ethically important, it raises the question of whether we are assessing the outcomes as a global commitment at all.

A more vivid debate has occurred around the criteria of who should be counted as poor (Pogge \& Reddy 2005, Ravallion 2008, Moore Lappé et al 2013). There are indeed various reservations about the existing data on poverty reduction and the embedded idea of poverty. Some of these expressed criticisms are technical. In large enterprises like global poverty data collection, an element of arbitrariness cannot be completely avoided. Following poverty trends involves a large number of technical and definitional issues even within a single country, let alone when the scope of the data is the whole world with all its diversity. The problems involved include data availability, for instance, where some countries and regions provide better data than others. Some countries may lack sufficient statistical capacity (Jerven 2013), or the data may vary in the degree to which they rely on generalisations. Poverty data can also include an element of political sensitivity in certain countries. (Walji 2015; DRG 2014).

Other problems relate to methodological choices. For example, in order to carry out any comparisons using a purchasing-power methodology, a representative 'basket of goods' needs to be defined. There is no objectively valid way to determine exactly which goods should be chosen to reflect the general price level in a country. An ideal 'basket' should reflect local tastes without being too particular, as well as the consumption capacities of different social classes. ${ }^{3}$ (Reddy 2006, Reddy \& Minoiu 2007). Furthermore, the choice of the unit of data has an impact on the observations. In practical terms, this means choosing whether to use an individual or a household as the unit. If the units are individuals, non-salaried members of wealthy households would - erroneously, it seems - be counted as poor. If the units are households, the divisions within the household are not articulated: for example, female members of very patriarchal families who fail to meet their basic needs are not counted as poor. 
Yet it is fair to say that these remarks do not raise great concern. They require acknowledging that there is a given margin of error in global poverty statistics. Some unavoidably arbitrary choices have an impact on poverty figures, and therefore the figures should not be seen as fully accurate reflections of reality. But all data collection involves a certain element of imprecision, so these issues can legitimately be considered unalarming. Economists and statisticians are also quite aware of these issues, and do their best to improve precision and make the necessary definitional choices as well grounded as possible (Ravallion 2008; Ravallion 1998).

A more serious set of issues emerges with definitional issues. As already mentioned, the official poverty line was set at US\$1.08 a day and was later adjusted to US $\$ 1.90$ a day, while the higher poverty line was initially set at US $\$ 2.00$ a day to later be adjusted to US\$3.10 a day. (For an official account, see Chen \& Ravallion 2001; Ravallion 1998). The problem with purely statistical definitions of development goals is evident in education, for example, where a quantitative increase in literacy is made suspect by the fact that definitions of literacy are ambiguous (UN 2017). Definitional issues lead to serious ethical questions in matters of poverty, as when 'poverty lines' are not determined on the basis of any ethically relevant criterion, such as an estimate of purchasing power needed for meeting basic needs, or being capable of exercising basic functionings. Rather the poverty line was determined by calculating the median of nationally defined poverty lines of fifteen poor countries (World Bank 2015). Thus it is a statistical figure that is methodologically based on other statistics, rather than directly on a conception of the necessary basics of life.

The poverty line has also been criticised for being too low, so that commanding a purchasing power above that threshold does not guarantee freedom from poverty. Some attempts to estimate a poverty line that corresponds with meeting basic needs have placed this poverty line considerably higher, to US\$3.00 a day in 2006 (Mandel 2006: 13), after which it would have been adjusted upwards along with the other poverty lines. ${ }^{5}$ There are therefore good reasons to believe that some people, whose living conditions would fail to meet a poverty line that ensures basic-needs, are cast as non-poor in the statistics that apply the official poverty line. The ethical conclusion must therefore be that while rising above any line is naturally lifeenhancing for a person living in poverty, the current official poverty lines do not necessarily reflect liberation from poverty in any ethically significant sense of the term.

Indeed, the justification given for the current official poverty lines is that purchasing-power adjusted poverty lines tend to be higher in wealthier countries, which reflects a rise in expectations along with the general living standard. Therefore placing the poverty line intentionally low is a deliberate way to eliminate any relative element in the definition of poverty (Ravallion 2008; Ravallion, Chen \& Sangraula 2009). In other words, the World Bank considers it more important that no one be erroneously categorised as poor (to avoid the relative element) than erroneously categorising someone as non-poor (to avoid seeing liberation from poverty in cases where it has not happened). This prioritisation necessarily reduces the number of poor statistically. Yet it seems ethically misguided, since overestimating the poor, or erroneously counting some non-poor as poor, will not harm anyone, but underestimating poverty can have such serious consequences. 
Returning to the poverty reduction trends, progress on the higher poverty line (US\$3.10, up from US\$2.00) is clearly slower than when one applies the lower poverty line (US\$1.90, up from US\$1.08). This implies that people liberated from extreme poverty tend to concentrate just above the lower poverty line. Keeping in mind that reflecting the requirements to meet basic needs would require applying an even higher poverty line, a real and alarming question surfaces: how impressive would poverty reduction actually be if such a higher poverty line were applied? No definite answer exists, since no comprehensive data is available to inform such an answer.

Furthermore, the poverty line does not recognise the identities of people above and below the line. This is of course sensible inasmuch as such data is and should be indifferent to identities in the sense of personal qualities. Yet the 'headcount' methodology is also indifferent to identities in terms of the development of individuals' economic situations, since it only counts the number of people. The incomes of people living in poverty tend to be very precarious, fluctuating constantly above and below the poverty line. The realities of poverty are not very well reflected by a methodology that insists on a sharp binary distinction between strict categories of poor and non-poor. The methodology informing the MDGs focuses on 'yesterday's rather than tomorrow's poverty' (Davala et al 2015: 2-3) and also fails to take into account this development of precarity, which is normally a necessary part of the evaluation of (dis)advantage (Wolff \& DeShalit 2013). Poverty reduction then becomes not a narrative of individual lives, but an observation that a larger number of people were above the poverty line than in a previous year of comparison. The same people might fluctuate above and below the poverty line. A decrease in poverty then simply shows that they are more likely than before to be above it.

Therefore, it is unclear whether improvements in poverty statistics mean that a given group of people is liberated from poverty, or that a larger group of people is living in a precarious state between poverty and non-poverty rather than in continuous poverty. This question clearly affects the ethical assessment. As a thought experiment, we can think of cases A and B. In case A, two people see their material living conditions change permanently for the better. In case $\mathrm{B}$, four people see their living conditions improving, but only to the degree that they enjoy a materially sufficient minimum living standard every other year on average, never knowing whether or not the year ahead will be one of sufficient living standards. In these cases, statistics show a similar development (two more people above the poverty line), but the cases are hardly ethically identical.

Some ethical implications of this issue follow. The MDG statistics show that people with very low incomes on average had more income in 2015 than they did in 2000. This is, by all accounts, a positive development. Yet concluding that their condition can be called 'liberation from poverty' in any ethical sense (suffering, capabilities, rights, etc) is premature, since many people may occasionally find themselves on either side of the poverty line. Other people see their incomes freeze just above the lower poverty line, as is shown by the varying rates of poverty reduction on different poverty lines. Some kind of 'borderline' category is needed that recognises the status of people whose living conditions are highly precarious, despite being - on average - above the lower poverty line. The ethical approach is not compatible with the sharp division between poverty and non-poverty, which currently dominates the methodology used. 


\section{Further ethical concerns about a purely statistical approach}

As noted above, the statistical definition of poverty shows only how many people live below the poverty line and nothing more, such as the means of poverty reduction or its geographical distribution. In this subchapter, I will discuss further concerns related to the purely statistical approach. First, how can one assess the implications of population growth? Second, what is the ethical significance of the fact that practically all poverty reduction policies also cause harm to some people, despite being effective and benefiting a larger group.

Owing to global population growth, the MDG-era poverty reduction appears considerably more successful when expressed in terms of the development of the proportion of people living in poverty rather than in terms of the number of people living in poverty. In fact, the degree of discrepancy between the two data interpretations is so wide that despite the observed success, it could even be concluded from another perspective that no progress has taken place for decades: the number of people living below the upper poverty line was indeed roughly the same in 2010 as it was in 1980 (World Bank 2017b).

MDG target-setting intentionally defined halving poverty in terms of proportions of humanity. Indeed some criticisms of the MDGs have pointed out that this definition makes the goals considerably less ambitious than the language of 'halving poverty' deceptively suggests (Pogge 2004). Yet no one has conclusively argued for the superiority of either interpretation as the correct method to measure poverty trends. On the one hand, referring to proportions can be seen as a statistically accurate method of observing changes in the condition of humanity at large. On the other, if extreme poverty is seen as a violation of rights, it would seem sensible to think of each human individual living in poverty as a moral problem.

In the ethical assessment of the proportional decline of people living below the poverty line, it can be useful to draw from another field of ethics, that of population axiology. In this field, the problem of 'adding more people' is often discussed: is it automatically good, if a generally satisfied person is added to the population, other things being equal (Parfit 1984: 381; Chan 2003; Carlson 1998)? While 'satisfied' cannot of course be equated with 'rich', the situation is comparable enough, if poverty is seen as ethically evil. So if halving the proportion of poor is seen as a relevant target, the automatic implication is that 'adding more people' who live above the poverty line is desirable: adding more people not living in poverty decreases the proportion of humanity living in poverty. If the target is put in terms of numbers of people living in poverty, this implication does not follow, at least not automatically. The latter seems to be an intuitively stronger position, as there is even an element of absurdity in seeing people 'added' above the poverty line as poverty reduction. Furthermore, it is possible to conceive of ethically highly condemnable means of decreasing the proportion of the poor in the population, such as involuntary family planning.

On the other hand, rapid population growth is associated with conditions of poverty rather than wealth; new people would typically be added in conditions of poverty. ${ }^{6}$ Therefore, again, it could be argued that the achieved poverty reduction is after all quite impressive, as it has to be assessed against a business-as-usual scenario. This scenario sees more people constantly added below the poverty line, making the situation constantly worse in terms of the proportion of humanity living in poverty. 
Quite another - but equally pressing - utilitarian consideration is related to the overall outcomes of the actual poverty-reducing policies. Poverty reduction takes place as an outcome of conscious policies and other human decisions. These policies not only give money and goods to poor people, other things remaining equal, but also bring about structural change, such as industrial development (China being the obvious recent example). This structural change can, like any large-scale societal change, also harm some people, contrary to the image created by the metaphor of 'lifting people from poverty'. To apply economic terminology, poverty reduction is hardly ever 'pareto-optimal', even when the overall outcome generally tends to be very positive in utilitarian terms. Indeed the MDG approach sees poverty as a problem with technical solutions, whereas in reality all policies include winners and losers.

It is possible to distinguish at least three kinds of cases with different ethical implications. First, poverty reduction policies can be harmful to some by their arbitrary selection of beneficiaries, resulting in greater income gaps and maldistribution of resources. A given poverty reduction policy could, for example, result in village A experiencing a leap in living standards, while equally or more deserving village $B$ remains economically stagnant. In such a situation, the residents of B could make plausible complaints, yet they are not worse off in absolute terms than before, making the situation pareto-optimal. Second, harm can come in the form of externalities. The most typical externality is industrial pollution, which can be a serious health hazard and have grave consequences for human functioning. While clearly harming people, the pollution does not manifest as poverty. Another similar case is the loss of aquacultural livelihoods and the so-called land grabs (Borras et al 2011; Magdoff 2013), which damage traditional livelihoods. These typically occur as side-effects of energy-production megaprojects such as dams, often seen as necessary for growth-enhancing - and thus poverty-reducing - industrial strategies. Third, harm can mean that some people become materially worse off as a result of a policy that lifts a larger number of people out of poverty. For instance, increases in productivity in agriculture typically result in better wages for some and unemployment for others. While the first category represents 'only' an injustice, the second category provokes questions about the plausible and implausible side effects of poverty reduction, and the third category forces wider questions about poverty reduction as a normative issue.

Related questions come in the form of limits of utilitarianism: what kinds of harm to people (if any) can be justified if the very same policies lift others out of poverty in larger numbers than those harmed? The first category relates to distributive justice and egalitarian treatment, while the other two raise the issue of rights. In strict right-based terms, no one should be subjected to serious harm for the sake of any greater good. A rights-based approach would indeed possibly lead to a very different kind of ethical assessment than the utilitarian approach on which the official poverty reduction discourse implicitly leans on.

To present the matter in a mechanical fashion, three scenarios $(A, B, C)$ can be distinguished for the purpose of a thought experiment:

A. Five people are liberated from poverty; no one is worse off

B. Seven people are liberated from poverty, while two others are pushed to poverty

C. Seven people are liberated from poverty, while one other is pushed to poverty 
In all scenarios, poverty prevalence has clearly decreased. In the sense of poverty as operationalised in the official poverty statistics, $\mathrm{C}$ is the superior scenario (six fewer people living in poverty), whereas $\mathrm{A}$ and $\mathrm{B}$ are worse than $\mathrm{C}$ and on par with each other (five fewer people living in poverty).

An alternative assessment would see $\mathrm{A}$ as the superior scenario as it is a pareto improvement, in contrast to $\mathrm{B}$ and $\mathrm{C}$. Intuitively, it would seem that there is some ethical difference between $\mathrm{A}$ and $\mathrm{B}$ so that scenario $\mathrm{A}$ is more desirable, even though in statistical headcount terms no difference exists. (This is of course a deliberately simplified model, omitting for instance the issue of pollution as an infringement of rights.)

An analysis of baselines should accompany the problem of a rights-based approach versus utilitarianism. In assessing poverty reduction success, is it sufficient to compare the current state to a historical situation, or should it be compared to a counterfactual situation? In other words, the ethical assessment of poverty reduction depends on the existence of plausible alternatives. If some poverty reduction policies are harmful to some poor people, are these the only plausibly conceivable policies? Harm to some individuals seems more justified if no plausible alternatives exist (given that harm can be justified at all). This illustrates the need to go to the level of comparing policy alternatives in addition to noting existing poverty trends.

The relevant points of comparison are indeed other plausible policies, rather than a historical baseline ${ }^{8}$, which is merely a notion of a past state, rather than even a business-as-usual scenario. For instance, it is of secondary importance that five people are liberated from poverty in scenario A, if a policy could just as easily have been chosen in which ten people would have experienced the same. This calls for reflection on the extent to which scenario A should be seen as an improvement. (Of course the remark is only theoretical, as there is no conclusive way to agree on what scenarios would qualify as plausible, given the complexity of global politics and the difficulty of estimating policy outcomes in advance.)

\section{The social and relational aspects of poverty}

Another noteworthy aspect of the MDG approach to poverty was seeing individuals as atomistic subjects, with no reference to their social surroundings. This is a natural outcome of the economistic methodology, which places individuals' purchasing power at the core of poverty, thus down playing the role of social factors. This is part of the ontology of economics more generally, but it is surprisingly seldom discussed in the methodological critiques of poverty measurement, which tend to focus more on technical than ontological matters.

The completely atomistic conception of the human being is naturally a methodological position rather than a substantial claim; the point is not to say that social ties have no significance to human beings, but that poverty can be analysed without reference to them. Yet this methodological atomism can also be called into question, if an ethically significant idea of poverty reduction is to be expressed. This is not because methodological atomism would be an ethically suspect position as such (rights theory in particular points to the contrary), but because of the relevance of the social surroundings to experienced poverty. In dire conditions, the safety nets provided by one's immediate surroundings can be as important as the level of income. 
Reference to the social context does not necessarily mean an insistence to discuss 'relative poverty'. While the experience of poverty is indeed contingent on the general level of income in the surrounding society, poverty reduction in the sense of liberating people from suffering and inhuman living conditions can be legitimately understood as a matter of escaping 'absolute poverty'. But the social context has relevance for absolute poverty as well. This is because the need for income to meet one's basic needs can vary between contexts beyond the purchasing power adjustment (Srinivasan 2008). If, say, a subsistence farmer commands a PPP income of US $\$ 1.90$ a day, s/he may be able to buy goods which will suffice for meeting basic needs. But if an urban dweller with little access to basic services, let alone to subsistence farming, must meet his/her basic needs with the same income, s/he is likely to suffer from severe deprivation. Extra-monetary issues, such as subsistence food production, unofficial community safety nets, access to basic services, or secured micro-ownership, can be more important than income levels. ${ }^{9}$ Some goods and services necessary for well-being are always produced outside the formal economy.

Significant trends are rapidly increasing the monetisation of life: urbanisation, and spatial concentration of jobs, leading to an increased need to commute (and for money to commute). These processes are often purposefully accelerated in the name of economic growth and, by implication, poverty reduction. On the other hand, processes with the reverse effect also exist, such as abolishing user fees for basic services such as schooling. Thus, several phenomena with direct relevance to the material conditions of people living in poverty are not recognised in the poverty statistics. For a person living in poverty, an increase in income improves the quality of life, given that other things remain constant. But it is also possible that other things are not constant, and the need for income increases. An issue of specific concern should be that monetary income can indeed increase while the command of basic goods decreases. Even official UN documents occasionally express the concern that 'viewed in terms of a wider definition of poverty [...] the situation today might be even more deplorable than the money income poverty line would suggest' (ESA 2010).

The unwillingness to recognise non-monetary means of survival is a longstanding current in western thought. Already in colonial times, economic efficiency and the related benefits for local people were used as a pretext to justify destroying local ownership patterns and the subsistence economy (Arnold 1988). This does not mean that there would be no need for poverty reduction in the conditions of a subsistence economy, because there certainly is. Rather it means that if the existing means for accessing basic goods are lost, a considerable increase of income is needed to avoid poverty, beyond a small push just above the poverty line. The main question of ethical significance thus revolves around what role money plays in living a life free from the evils associated with poverty. In other words, levels of income can be comparable in a meaningful sense only within a given social setting; beyond that, observations of statistical trends should be accompanied by an understanding of the change of the social form in order to be ethically meaningful.

How well the monetary baselines and the real-life experiences overlap is an empirical rather than an ethical issue. Since no automatic overlap exists, there is a risk of recommending poverty reduction policies that in fact increase experienced poverty. The empirical question of the level of income needed to meet basic needs should then be answered before landing on conclusive ethical positions about the 
achieved poverty reduction, even though unconfirmed and preliminary ideas will be necessary along the way.

\section{Conclusions}

I have discussed the ethical significance of poverty reduction associated with the Millennium Development Goals. As noted, statistical and ethical definitions of poverty never completely overlap. This discrepancy, along with other findings on the poverty reduction of the MDG era, point to the need to address questions of how poverty reduction should be defined in order to be ethically meaningful. Some (minor) issues are related to margin of error and other methodological reservations. Furthermore, a valid question is how global the MDG outcomes actually are, since success appears to be geographically quite uneven.

The more pressing issues include at least three separate sets of questions. First, what is the ethical significance of changes in terms of numbers of people suffering from poverty vis-à-vis the proportion of people suffering from poverty? Second, further ethical problems relate to the identities of people above and below a poverty line. While a headcount aggregate shows positive changes in poverty prevalence, individuals may see their incomes fluctuate above and below the poverty line. This means that instead of being securely liberated from poverty, a large number of people experience a constant risk of falling into poverty, although this risk materialises less often than before. Third, it is always possible that some people are pushed to poverty as a result of poverty-reducing social transformation. Therefore, a thorough ethical analysis of MDG success would require one to identify how close to pareto-optimality poverty reduction successes are, and how secure the position of individuals is who have recently risen above the poverty line. Assessing feasible alternative political scenarios should also be part of the analysis. Statistical data in the form of aggregate numbers are blind to the possible suffering of some people as a result of policies causing greater good. Ethicists should debate to what extent this possibility should affect the normative judgement of global developments, as impressive as they may be.

A further issue - that extends to the very definition of poverty - arises from the question as to whether an individual who is detached from his/her social surroundings is actually a relevant methodological subject in poverty measurements. This does not infer an argument for seeing only relative poverty (level of income relative to others in the society) as relevant; the point is rather that a given income should be accompanied by an analysis of how bearable this income level is in the given social setting.

The various points discussed in this article point to the need to deepen the ethical assessment of poverty reduction. This is vital in order to have an ethically accurate idea of important global developments; but also because ethical deliberation can better inform future official conceptions of poverty, since both the definition and operationalisation of poverty are subject to change. Without a thorough assessment of the MDGs as an ethical achievement, mistakes are much more likely. As has been shown above, the current poverty reduction methodology is an insufficient tool to analyse ethically meaningful changes, which could more suitably be analysed in terms of other measures, such as human development and capabilities. The current Sustainable Development Goals include more relational interpretations of poverty that explicitly address inequalities, rather than only poverty. ${ }^{10}$ The official 
conception of poverty keeps changing, and ethical analysis should inform these changes.

\section{Notes}

${ }^{1}$ On the distinction between access and command, see Sen 1992: 31-34.

2 A noteworthy exception in the ethics of poverty is the idea of 'lifeboat ethics' (Hardin 1974) and other similar Malthusian approaches, which see poverty reduction as detrimental in the long run, because of the contrasting dynamics of resources and population.

${ }^{3}$ A perennial issue is that the 'basket' ought to be both empirically representative, i.e. what the poor most often buy, and morally significant, i.e. including things which are necessary for human dignity and survival; and these do not automatically fully overlap. In any research of this sort, this problem is unavoidable; whatever you choose to be included in the basket can always be criticised for including that given good and omitting some other.

${ }^{4}$ Another issue is the possibility of deliberate misinterpretation, which is a common accusation of statistics (see for instance Levitas \& Guy 1996). Yet no evidence of such exists in the case of global poverty statistics.

${ }^{5}$ For further criticism on adjusting a poverty line, see Mehta 2005.

${ }^{6}$ Currently, the population growth rate average in LDCs (Least developed countries) is $2,4 \%$, and in OECD countries $0,7 \%$ (World Bank 2018).

${ }^{7}$ A 'pareto-optimal' development is one after which no one is worse off than before, while others can be better off. Non-pareto-optimal development is then a case in which some people are worse off than before, even though the development might be positive in utilitarian terms.

${ }^{8}$ For a defence of the historical baseline approach, see Risse 2005a, $2005 \mathrm{~b}$.

9 The poverty lines informing the MDG statistics took a very clear position, applying almost a uniform poverty line for the planet (World Bank 2015; Ravallion 1998), only allowing limited variation for rural vs. urban conditions.

${ }^{10}$ The SDGs have of course also been subject to critical scrutiny. As for philosophical papers, there have been critical questions expressed regarding unclarity about the content of 'sustainability' and 'equality' (Camacho 2015); unclarity about priorities (Pongiglione 2015), and the structure of the SDGs (Wisor 2015).

\section{References}

Arnold, D. (1988). Famine. Social crisis and historical change. Oxford: Basil Blackwell.

Borras, S.; Hall, R.; Scoones, I.; White, B. \& Wolford, W. (eds.) (2011). Journal of peasant studies 38(2). Special issue on land grabbing.

Camacho, L. (2015). Sustainable development goals: kinds, connections and expectations. Journal of global ethics 11:1, 18-23. https://doi.org/10.1080/ 17449626.2015.1010097

Campbell, T. (2007). Poverty as a violation of human rights: inhumanity or injustice? In Thomas Pogge (ed.) Freedom from poverty as a human right: Who owes what to the very poor? Oxford: Oxford University press.

Carlson, E. (1998). Mere addition and two trilemmas of population ethics. Economics and philosophy 14 (2), 283-306. https://doi.org/10.1017/ S0266267100003862 
Chan, K.M.A. (2003). Intransitivity and future generations: Debunking Parfit's mere addition paradox. Journal of applied philosophy 20 (2), 187-200. https://doi.org/10.1111/1468-5930.00245

Chen, S. \& Ravallion, M. (2001). How did the world's poor fare in the 1990's? Review of income and wealth 40 (4), 359-376. https://doi.org/10.1111/j.14754991.1994.tb00081.x

Davala, S.; Jhabvala, R.; Mehta, S.K. \& Standing, G. (2015). Basic Income. A transformative policy for India. London \& New York: Bloomsbury.

Dower, N. (1991). World poverty. In Peter Singer (ed.), A companion to ethics. Oxford: Blackwell.

DRG (Data Revolution Group) (2014). A world that counts. Mobilising the data revolution for sustainable development. Retrieved 15 September 2017 from http://www.undatarevolution.org/wp-content/uploads/2014/12/A-WorldThat-Counts2.pdf

ESA (Department of economic and social affairs of the United Nations) (2010): Rethinking poverty. Report on the world social situation 2010.

Galatsihas, A. \& Sheedy, F. (2015). What have the millennium development goals achieved? Retrieved 15 September 2017 from http://www.theguardian.com/ global-development/datablog/2015/jul/06/what-millennium-developmentgoals-achieved-mdgs

Gordon, D. (2005). Indicators of poverty and hunger. Retrieved 15 September 2017 from http://www.un.org/esa/socdev/unyin/documents/ydiDavidGordon _poverty.pdf

Hardin, G. (1974). Lifeboat ethics. The case against helping the poor. Psychology Today, September 1974.

Jerven, M. (2013). Poor numbers: How we are misled by African development statistics and what to do about it. Ithaca, NY: Cornell University press.

Levitas, R. \& Guy, W. (eds.) (1996). Interpreting official statistics. Andover: Routledge.

Magdoff, F. (2013). Twenty-first century land grabs. Accumulation by agricultural dispossession. Monthly Review 65 (6) (online article). https://doi.org/ 10.14452/MR-065-06-2013-10_1

Mandel, S. (2006). Debt relief as if people mattered. London: New Economics Foundation.

Mehta, J. (2005). Poverty in India. In The Alternative Economic Survey 2003-04. London: Zed Books.

Moore Lappé, F.; Clapp, J.; Anderson, M.; Broad, R.; Messer, E.; Pogge, T. \& Wise, T. (2013). How we count hunger matters. Ethics \& International Affairs 17 (2), 251-259. https://doi.org/10.1017/S0892679413000191

Nagel, T. (2008). Poverty and food: why charity is not enough? In Pogge, Thomas \& Moellendorff, Darrel (eds.) (2008). Global justice. Seminal essays. St Paul, MN: Paragon House.

Nussbaum, M. (2001). Women and human development. The capabilities approach. Cambridge: Cambridge University Press.

ONE (2016) ONE frontpage. Retrieved 15 September 2017 from http://www.one.org/international/ 
O'Neill, O. (2008). Rights, obligations and world hunger. In Pogge, Thomas \& Horton, Keith (eds.) Global ethics. Seminal essays. St Paul, MN: Paragon House.

Parfit, D. (1984). Reasons and persons. Oxford: Oxford University Press.

Pogge, T. (2004). The first United Nations Millennium Development Goal: a cause for celebration? Journal of human development and capabilities 5 (3), 377-397. https://doi.org/10.1080/1464988042000277251

Pogge, T. (2008). "Assisting" the global poor. In Pogge, Thomas \& Horton, Keith (eds.) (2008), Global ethics. Seminal essays. St Paul, MN: Paragon House.

Pogge, T. \& Reddy, S. (2005). How not to count the poor. In Anand, Segal \& Stiglitz (eds.), Debates on the measurement of global poverty. Oxford: Oxford University Press. https://doi.org/10.2139/ssrn.893159

Pongiglione, F. (2015). The need for a priority structure for the Sustainable Development Goals. Journal of global ethics 11:1, 37-42. https://doi.org/ 10.1080/17449626.2014.1001912

POP (2016) Welcome to People Against Poverty. Retrieved 15 September 2017 from http://www.peopleagainstpoverty.com/

Rahnema, M. (1992). Poverty. In Wolfgang Sachs (ed.), The development dictionary. A guide to knowledge as power. London: Zed Books.

Ravallion, M. (2008). How not to count the poor? A reply to Pogge and Reddy. In Anand, Segal \& Stiglitz (eds.), Debates on the measurement of global poverty. Oxford: Oxford University Press.

Ravallion, M. (1998). Poverty lines in theory and practice. Living standards measurement study working paper 133. World Bank, Washington DC. https://doi.org/10.1596/0-8213-4226-6

Ravallion, M.; Chen S. \& Sangraula, P. (2009). Dollar a Day Revisited. The World Bank economic review 23:2, 163-184. https://doi.org/10.1093/wber/lhp007

Reddy, S. (2006). Counting the poor. The truth about world poverty statistics. The socialist register 2006. London: Merlin.

Reddy, S. \& Camelia M. (2007). Has world poverty really fallen? Review of income and wealth 53 (3), 484-502. https://doi.org/10.1111/j.1475-4991.2007. 00240.x

Risse, M. (2005a). How Does the Global Order Harm the Poor?, Philosophy and Public Affairs 33:4, 349-376. https://doi.org/10.1111/j.1088-4963.2005. 00036.x

Risse, M. (2005b). Do We Owe the Poor Assistance or Rectification? Ethics and International Affairs 19:1, 9-18. https://doi.org/10.1111/j.1747-7093.2005. tb00485.x

Sane, P. (2010). Rethinking poverty: A human rights perspective. Oxford: Blackwell.

Sen, A. (1999). Development as freedom. Oxford: Oxford University Press.

Sen, A. (1992). Inequality re-examined. Cambridge, MA: Harvard University Press.

Singer, P. (2008). Famine, affluence and morality. In Pogge, T. \& Horton, K. (eds.) (2008) Global ethics. Seminal essays. St Paul, MN: Paragon House.

Srinivasan, T.N. (2008). Irrelevance of the $\$ 1$-a-day poverty line. In Anand, Segal \& Stiglitz (eds.), Debates on the measurement of global poverty. Oxford: Oxford University Press.

Sumner, A. (2012). From Deprivation to Distribution: Is Global Poverty Becoming A Matter of National Inequality? IDS Working Paper. Brighton: IDS. 
UN (United Nations) (2000). United Nations Millennium Declaration. Retrieved 15 September 2017 from http://www.un.org/millennium/declaration/ ares552e.htm

UN (United Nations) (2015a). MDGs produced most successful anti-poverty movement in history. UN report. Retrieved 15 September 2017 from http://www.undp.org/content/undp/en/home/presscenter/pressreleases/2015/ 07/06/mdg-s-produced-most-successful-anti-poverty-movement-in-historyun-report.html

UN (United Nations) (2015b). The Millennium Development Goals Report 2015. New York: United Nations.

UN (United Nations) (2015c). The Millennium Development Goals 2015. New York: United Nations.

UN (United Nations) (2016). Goal 1: End poverty in all its forms everywhere. Retrieved 15 September 2017 from http://www.un.org/sustainable development/poverty/

UN (United Nations) (2017). Indicator metadata. Goal: Goal 2. Achieve universal primary education. Indicator Name: 2.3 Literacy rate of 15-24 year-olds, both sexes. Retrieved 05 March 2018 from http://mdgs.un.org/unsd/mdg/ SeriesDetail.aspx? srid $=656$

UNDP (2018) Human Development Index (HDI). Retrieved 05 March 2018 from http://hdr.undp.org/en/content/human-development-index-hdi

WHO (2017). Eradicate extreme poverty and hunger. Retrieved 15 September 2017 from http://www.who.int/topics/millennium_development_goals/hunger/en/

Unger, P.(1996). Living high and letting die. Oxford: Oxford University Press. https://doi.org/10.1093/0195108590.001.0001

Walji, A. (2015). Big gaps and big data. Perspectives on development blog 30.3.2015. Retrieved 15 September 2017 from http://blogs.worldbank.org/ voices/big-gaps-and-big-data

Wisor, S. (2015). On the structure of global development goals. Journal of global ethics 11:3, 280-287. https://doi.org/10.1080/17449626.2015.1084024

Wolff, J. \& DeShalit, A. (2013) Disadvantage. Oxford: Oxford University Press.

World Bank (2015). FAQs: Global poverty line update. Retrieved 15 September 2017 from http://www.worldbank.org/en/topic/poverty/brief/global-poverty-linefaq

World Bank (2017a). What are poverty lines? Retrieved 15 September 2017 from http://www.worldbank.org/en/news/video/2017/04/14/what-are-poverty-lines

World Bank (2017b). World Bank poverty and equity database. Retrieved 15 September 2017 from http://databank.worldbank.org/data/

World Bank (2018) Population growth (annual \%). Retrieved 05 March 2018 from https://data.worldbank.org/indicator/SP.POP.GROW 